\title{
GMR
}

\section{Genetic and molecular characterization of multiflorous spikelet in oat}

\author{
C.M. Zimmer, I.P. Ubert, K. Pellizzaro, L.C. Federizzi and I.C. Nava \\ Departamento de Plantas de Lavoura, Universidade Federal do Rio Grande do Sul, \\ Porto Alegre, RS, Brasil \\ Corresponding author: I.C. Nava \\ E-mail: itamar.nava@ufrgs.br
}

Genet. Mol. Res. 16 (1): gmr16019588

Received December 20, 2016

Accepted February 16, 2017

Published March 30, 2017

DOI http://dx.doi.org/10.4238/gmr16019588

Copyright (C) 2017 The Authors. This is an open-access article distributed under the terms of the Creative Commons Attribution ShareAlike (CC BY-SA) 4.0 License.

ABSTRACT. Multiflorous spikelets are found in several grass species
of agricultural and economic interest. In oat, this morphological
characteristic is associated with the production of naked grains. Although
many genetic studies have been performed over the past century, the
inheritance of the multiflorous spikelet trait is not fully understood
in oat. The objectives of this study were to evaluate environmental
effects on the multiflorous spikelet trait, to estimate the number of
genes controlling the trait, and to clone and characterize sequences of
the $A P 2$ gene in oat. Two genetic populations of recombinant inbreed
lines were screened for the multiflorous spikelet trait from different
years and sowing dates under field experiments. Normal, multiflorous,
and mosaic spikelets were analyzed in the whole panicle for both
years and sowing dates. Specific primer pairs for the AP2 gene was
utilized to amplify and clone oat sequences. The results demonstrate
that under higher temperature and day-length conditions, the variable
expressivity of the multiflorous spikelet trait was less pronounced in
both populations. Genetic analyses indicated the action of one major
gene and two or three modifying genes controlling the expression of the
multiflorous spikelet trait in oat, depending on the genetic background.

Genetics and Molecular Research 16 (1): gmr16019588 
Sequences with similarity to the $A P 2$ gene were isolated from the oat lines UFRGS 017004-2 and URS Taura, and genetic polymorphisms were identified, which are valuable to confirm the action of $A P 2$ on the multiflorous spikelet trait. Our results provide information to assist in the development of future studies of the multiflorous spikelet trait in oat.

Key words: AP2 gene family; Indeterminate spikelets; Naked oat; SNP markers

\section{INTRODUCTION}

Multiflorous spikelets are found in several species within the genus Avena, including Avena clauda and Avena sterilis (Ladizinsky, 2012). Naturally occurring mutations in the ancestor species $A$. sterilis resulted in reduced natural seed dispersal and loss of germination inhibition during the evolution of this species. These mutations were crucial for the emergence of the cultivated oat species Avena sativa L. $(2 \mathrm{n}=6 \mathrm{x}=42$, AACCDD) (Leggett and Thomas, 1995; Loskutov, 2008). Other mutation events in the genus Avena led to the formation of different species and subspecies showing multiflorous spikelet and naked grain traits. The possible center of origin and diversity of the naked oat, A. sativa subsp nudisativa, is Mongolia and Northwest China. In this region, the species remained geographically isolated, which explains its morphological differences when compared to the cultivated oat. Archaeological evidence suggests that naked oat has been cultivated in China for 2500 years (Vavilov, 1992).

Cultivated oat is an important cereal crop worldwide, and presents hulled grains and normal spikelets. A normal spikelet contains two or three fertile florets per spikelet, with each floret producing one grain (Valentine, 1995). In comparison, naked oat has multiflorous spikelets, elongated rachilla, and four to 12 fertile florets per spikelet (Burrows, 1986). In oats, the formation of multiflorous spikelets is phenotypically associated with the production of naked grains. However, variable expression of the multiflorous spikelet trait limits our understanding of its inheritance, since individuals with the same genotype do not show the same phenotype. The expression of this trait can vary among plants, among panicles within the same plant, and even within the same panicle (Pellizzaro et al., 2016).

Genetic and evolutionary mechanisms underlying the formation of multiflorous spikelets in hexaploid oat are not yet fully understood. The inheritance of the multiflorous spikelet trait has been investigated in several studies over the past century, and the results have indicated that the action of a major gene controls the trait and has a strong effect on the phenotype (Caporn, 1918; Love and McRostie, 1919; Boland and Lawes, 1973; Kibite and Taylor, 1994; Cabral et al., 2000). However, oat breeders and researchers believed that this major gene also participated in the formation of naked grains (Simons et al., 1978; Ougham et al., 1996). A genetic model proposed by Kibite and Taylor (1994) suggested that the action of two distinct genes were involved: Multiflorous1 ( $M f 1$ ), which controls the formation of multiflorous spikelets, and Nakedl (N1), which controls the formation of naked grains. The strength of the two separated gene model was verified by analysis of phenotypic data involving the joint segregation of $N 1$ and $M f 1$, in which an extremely low recombination frequency was observed (Kibite and Taylor, 1994). These results justify the strong association between the multiflorous spikelet and naked grain phenotypes.

Genetics and Molecular Research 16 (1): gmr16019588 
In several grass species, including wheat (Triticum aestivum L.), barley (Hordeum vulgare L.), rice (Oryza sativa L.), and maize (Zea mays L.), genes from the APETALA2 (AP2) gene family, which encode transcription factors, are required for the formation of multiflorous spikelets (Chuck et al., 2002, Chuck et al., 2008; Lee and An, 2012; Poursarebani et al., 2015; Sormacheva et al., 2015). Thus, the Mf1 gene previously reported by Kibite and Taylor (1994) could be a member of the AP2 gene family. In wheat, the $Q$ gene belongs to the AP2 gene family, and has been described as wheat AP2 (WAP2), which plays a central role in the regulation of many traits including spike shape, rachis fragility, and naked grains (Faris et al., 2003; Sormacheva et al., 2015). The positionally cloned gene compositum 2 (com2), underlying spike-branching in barley is orthologous to the branched headt $\left(b h^{t}\right)$ locus (Poursarebani et al., 2015), which regulates spike branching on each rachis node in wheat (Klindworth et al., 1997). Both com2 and $b h^{t}$ are orthologous to genes with similar functions, BRANCHED SILKLESS1 (BD1) in maize and FRIZZY PANICLE/BRANCHED FLORETLESS1 (FZP/BFL1) in rice (Komatsu et al., 2003; Zhu et al., 2003).

The objectives of this study were to characterize the multiflorous spikelet phenotype in recombinant inbred oat lines evaluated in different years and sowing dates, to determine the number of genes controlling the trait, and to clone and characterize candidate sequences associated with the AP2 gene family using sequence information from other grass species. Our results demonstrate that under higher temperature and day-length conditions, the variable expressivity of the multiflorous spikelet trait was less pronounced in both populations. Genetic analyses indicated that the action of one major gene and two or three modifying genes control the expression of the multiflorous spikelet trait in oat, depending on the genetic background. Sequences with similarity to the $A P 2$ gene were isolated in oat and genetic polymorphisms were identified.

\section{MATERIAL AND METHODS}

\section{Genetic populations}

Two genetic populations of recombinant inbred lines (RILs) developed from the single crosses 'UFRGS 01B7114-1-3 x UFRGS 006013-1' and 'URS Taura x UFRGS 017004-2', herein described as 'U01B x U006' and 'UTau x U017', respectively, were analyzed in this study. The parental lines of each genetic population were developed by the Oat Breeding Program of the Federal University of Rio Grande do Sul (UFRGS), Brazil. The parental lines UFRGS 01B7114-1-3 and URS Taura are hulled lines presenting panicles with 100\% normal spikelet phenotypes. The contrasting parental lines, UFRGS 017004-2 and UFRGS 0060131, present panicles with $100 \%$ multiflorous spikelets and variable expressivity for the trait, respectively. Both populations of oat RILs were developed by the single-seed descent method, without selection, in order to preserve the genetic variation among the RILs up to advanced generations of self-fertilization.

\section{Field experiments}

Parental lines and RILs from the crosses 'U01B x U006' and 'UTau x U017' were included as entries in field experiments. These experiments were designed to measure differences in the formation and development of multiflorous spikelets over different years

Genetics and Molecular Research 16 (1): gmr16019588 
and sowing dates. From the two crosses, a total of 144 and 191 RILs were screened in the growing season of 2013 (June-November), respectively. For each genotype (parental line or RIL), seeds from an individual panicle were sown in 2-m long double rows in the field, with $0.20 \mathrm{~m}$ between rows and $0.40 \mathrm{~m}$ between plots. A total of 92 RILs from the cross ' $\mathrm{U} 01 \mathrm{~B} \mathrm{x}$ U006', and 90 RILs from the cross 'UTau x U017' were evaluated from two sowing dates during the 2014 growing season, June 12 and July 4, in a randomized complete block design, replicated twice. Each experimental unit consisted of a hill, and the hill plots were spaced $0.30-\mathrm{m}$ apart in each row, with the rows $0.40-\mathrm{m}$ apart. Sowing was carried out manually at a density of 15 seeds for hulled RILs and 20 seeds for unhulled RILs. The different numbers of hulled and unhulled RIL seeds were associated with the lower rate of germination usually present in naked oat genotypes relative to hulled oat genotypes.

The field experiments were conducted at the UFRGS Agronomy Experimental Station, located in Eldorado do Sul, Southern Brazil. In 2014, the temperature and rainfall varied during the experiments carried out on the first and second sowing date. Meteorological data were associated with phenotypic variation in the multiflorous spikelet trait and used to better understanding environmental influences on the expression of this trait under field conditions. When plants grown in each year and sowing date reached maturity, approximately 12 panicles of each parental line and RIL were randomly collected in the field. These panicles were used for the phenotypic screening of the multiflorous spikelet trait.

\section{Phenotypic screening of the multiflorous spikelet trait}

The phenotypic expression of the multiflorous spikelet trait in 2013 was analyzed using six individual panicles for each parental line and RIL. For the 2014 growing season, eight individual panicles from each sowing date were evaluated for each parental line and RIL. Phenotypic screening involved the detailed classification of each spikelet within the panicle. Determinate and indeterminate spikelet growth patterns were observed among the RILs evaluated for both populations. The determinate pattern includes panicles that produce $100 \%$ normal spikelets, with two to three fertile florets and grains adhered to well-lignified lemma and palea (Figure 1A). Conversely, the indeterminate pattern can be divided into two main classes: i) absence of variable expressivity, which is composed of panicles that produce $100 \%$ multiflorous spikelets, with four or more fertile florets, elongated rachilla, and grains coated with soft glumes (Figure 1B); and ii) presence of variable expressivity at differentiated levels, leading to the production of panicles exhibiting different types of mosaic, depending on the spikelet present within the panicle. The mosaic phenotypes observed in this study were termed as follows: type A mosaic, presence of only normal and multiflorous spikelets within the panicle; type B mosaic, presence of normal and mosaic spikelets (hulled and unhulled grains in the same spikelet) within the panicle (Figure 1C); type $\mathrm{C}$ mosaic, presence of multiflorous and mosaic spikelets within the panicle; and type D mosaic, presence of normal, multiflorous and mosaic spikelets within the panicle.

As the number of spikelets per panicle varied among RILs, the observed number of normal, multiflorous, and mosaic spikelets was transformed into a percentage. A frequency distribution analysis was carried out for each year and sowing date. Variance analyses were used to detect differences among RILs for the multiflorous spikelet trait evaluated on different sowing dates in 2014. Frequency distribution and variance analyses were carried out using SAS 9.4.

Genetics and Molecular Research 16 (1): gmr16019588 
A

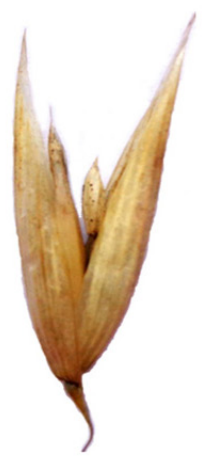

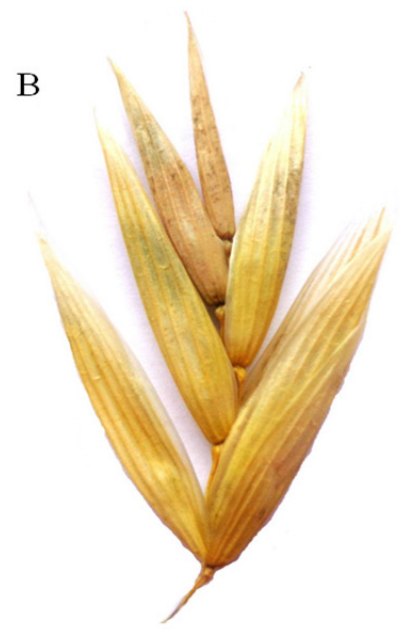

$\mathrm{C}$

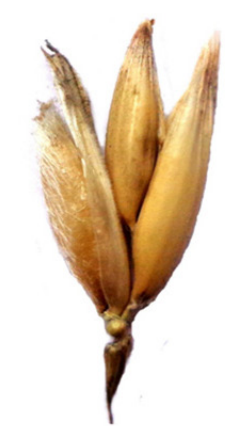

Figure 1. Characterization of the different spikelet phenotypes produced in hexaploid oat. A. Normal spikelet; B. multiflorous spikelet; and C. mosaic spikelet. For the mosaic spikelet phenotype, glumes and palea structures were intentionally removed with the aim of better visualizing the presence of naked and hulled grains in the same spikelet.

\section{Genetics of the multiflorous spikelet trait}

Genetic analyses were divided into two main steps. In the first step, the genetic hypothesis of 'one major gene' was tested to elucidate the inheritance of determinate and indeterminate spikelet growth patterns. Considering lines as fixed/homozygous, a ratio of one determinate RIL to one indeterminate RIL was expected in the genetic populations 'U01B $\mathrm{x}$ U006' and 'UTau x U017'. The observed frequencies were compared to the expected frequencies by chi-square $\left(\chi^{2}\right)$ goodness-of-fit tests at a $5 \%$ significance level, according to the method described by Steel and Torrie (1980). In the second step, different genetic hypotheses were tested in order to elucidate the genetic factors underlying phenotypic variation in the indeterminate spikelet growth pattern, and to verify the action of modifying genes over the major gene defined in step one. The genetic hypotheses were tested as follows: i) the action of one major gene and two modifying genes, with the expected frequencies of $1 / 8$ of the RILs presenting $100 \%$ multiflorous spikelets, $3 / 8$ of the RILs presenting some level of variable expressivity (type A, B, C, or D mosaic), and 4/8 of the RILs presenting 100\% normal spikelets; and ii) the action of one major gene and three modifying genes, with the expected frequencies of $1 / 16$ of the RILs presenting $100 \%$ multiflorous spikelets, $7 / 16$ of the RILs presenting some level of variable expressivity (type A, B, C, or D mosaic), and 8/16 of the RILs presenting $100 \%$ normal spikelets. The observed frequencies were compared to the expected frequencies by chi-square $\left(\chi^{2}\right)$ goodness-of-fit tests at a $5 \%$ significance level, according to the method described by Steel and Torrie (1980).

\section{DNA isolation and purification}

Fifteen random seeds derived from an individual panicle of each parental line, URS Taura (normal spikelets) and UFRGS 017004-2 (multiflorous spikelets) were germinated in 
a plastic box. When plants were approximately 7-cm tall, 0.1-0.2 g of coleoptile tissue was collected from at least six plants per parental line. Immediately after, tissue samples were frozen in liquid nitrogen, ground, and stored at $-70^{\circ} \mathrm{C}$. DNA was extracted using a modified cetyltrimethylammonium bromide method. Sodium chloride and polyvinylpyrrolidone were used to remove polysaccharides and polyphenols, respectively, following the procedures described by Pellizzaro et al. (2016).

\section{Cloning of candidate gene sequences from contrasting genotypes}

A total of 30 sequences related to the AP2 gene family from grass species, including wheat, barley, false bromus (Brachypodium distachyon), maize, and foxtail millet (Setaria italica) were retrieved from GenBank (http://www.ncbi.nlm.nih.gov/genbank). Many rounds of multiple alignments with different sequence combinations were tested using the CLUSTAL W tool (Thompson et al., 1994) add-in module within the BioEdit Sequence Alignment Editor (Hall, 1999). From these alignments, one sequence of the $A P 2$ gene derived from wheat (accession 543013) and one sequence of the gene derived from false bromus (accession 100828894) were used to produce a consensus template sequence. The consensus sequence represents genomic regions within the $A P 2$ gene that are conserved between the aligned sequences, which were used for primer development. A specific primer pair combination anchored in conserved coding regions was designed online using Primer3Plus (http://www. bioinformatics.nl/cgi-bin/primer3plus/primer3plus.cgi/). This primer pair was named 'AP2.7' and the corresponding sequences were AGCGACTACGAGGACGACAT (forward) and CCTAGCACATATGAGGGGGA (reverse).

Polymerase chain reactions (PCRs) were conducted in a C1000 Touch $^{\mathrm{TM}}$ Thermal Cycler (Bio-Rad Laboratories, Hercules, CA, USA) to amplify oat sequences of the $A P 2$ gene. PCR was conducted in a final volume of $50 \mu \mathrm{L}$ containing: $1.5 \mathrm{mM} \mathrm{MgCl}_{2}, 500 \mu \mathrm{M}$ dNTP, 1 U Taq DNA polymerase (Invitrogen, Carlsbad, CA, USA), 1X PCR buffer (as supplied by the manufacturer), $1 \mu \mathrm{M}$ each primer, and $90 \mathrm{ng}$ genomic DNA. The amplification conditions were as follows: $3 \mathrm{~min}$ at $94^{\circ} \mathrm{C}$, followed by 40 cycles of $30 \mathrm{~s}$ at $94^{\circ} \mathrm{C}, 45 \mathrm{~s}$ at $57^{\circ} \mathrm{C}, 2 \mathrm{~min}$ at $72^{\circ} \mathrm{C}, 10 \mathrm{~min}$ at $72^{\circ} \mathrm{C}$, and hold at $4^{\circ} \mathrm{C}$. PCR products (amplicons) were resolved on $1.5 \%$ agarose gels and visualized by ethidium bromide staining.

Amplified fragments of the expected size were isolated from agarose gels and purified using the PureLink ${ }^{\circledR}$ Quick Extraction kit (Invitrogen). Purified DNA was ligated into the vector $\mathrm{PCR}^{\mathrm{TM}}$ 2.1-TOPO ${ }^{\circledR}$ (Invitrogen) and transformed into Escherichia coli (XL-1 Blue). Twelve random colonies from each ligation and transformation were inoculated in Luria-Bertani (LB) liquid medium (Sigma-Aldrich, St. Louis, MO, USA), containing tetracycline and kanamycin as selective agents and then incubated at $37^{\circ} \mathrm{C}$ under shaking conditions overnight for 14 h. After incubation, tubes containing the medium and multiplied cells were centrifuged for $8-10 \mathrm{~min}$ at $8000 \mathrm{rpm}$. The pellet was re-suspended in $500 \mu \mathrm{L} 10 \mathrm{mM} \mathrm{MgSO}_{4}$, boiled at $100^{\circ} \mathrm{C}$ for $10 \mathrm{~min}$, centrifuged for $5 \mathrm{~min}$ at $12,500 \mathrm{rpm}$, and the supernatant was stored at $4^{\circ} \mathrm{C}$. Inserts were amplified using M13 universal primers in two main reactions. In the first reaction, tubes containing ultra-pure water, PCR Taq buffer, $\mathrm{MgCl}_{2}$, and template DNA (from the DNA suspended in $\mathrm{MgSO}_{4}$ ) were held for $30 \mathrm{~min}$ at $94^{\circ} \mathrm{C}$. In the second reaction, dNTPs, M13 primers, and Taq DNA polymerase were added to the PCR. Inserts were sequenced using an ABI 3500 Genetic Analyzer (Applied Biosystems, Carlsbad, CA, USA).

Genetics and Molecular Research 16 (1): gmr16019588 


\section{In silico analysis}

The basic linear alignment sequence tool, BLAST (Altschul et al., 1990) was used to verify nucleotide similarities between putative oat $A P 2$ gene sequences and related sequences available at GenBank. Oat sequences from the parental lines URS Taura (normal spikelets) and UFRGS 017004-2 (multiflorous spikelets) derived using the 'AP2.7' primer pair were aligned and the level of genetic polymorphism was estimated by the frequency of single nucleotide polymorphisms (SNP) present among the sequences. A putative open reading frame (ORF) was identified for these oat genomic sequences with nucleotide similarity to the $A P 2$ gene. The three-dimensional structure of the protein for the oat genotypes URS Taura and UFRGS 017004-2 was predicted using the platform SWISS-MODEL (http://swissmodel.expasy.org) and visualized using the program RasMol Version 2.7.5.2 (Sayle and Milner-White, 1995). Oat sequences targeting the $A P 2$ gene were converted to mRNA and aligned with a microRNA172a (miR172a) sequence from B. distachyon (accession MI0018110), available at miRBase (http:// www.mirbase.org). Figures for each alignment were produced using the program GeneDoc.

\section{RESULTS}

\section{Phenotypic screening of the multiflorous spikelet trait}

Wide phenotypic variation was observed for the multiflorous spikelet trait among the evaluated RILs between different years and sowing dates. For the 'U01B x U006' population screened in 2013, the frequency distribution of the multiflorous spikelet trait demonstrated that 66 RILs expressed a determinate spikelet pattern showing 100\% normal spikelets, while only five RILs expressed an indeterminate spikelet pattern with no variable expressivity and $100 \%$ multiflorous spikelets (Figure 2A and 2B). The remaining 73 RILs expressed an indeterminate spikelet pattern with variable expressivity, in which four RILs showed type A mosaic spikelets and 69 RILs showed some level of mosaic spikelets (type B, C, or D) (Figure 2C).

The frequency distribution of the multiflorous spikelet trait for the 'UTau x U017' population demonstrated that 106 RILs expressed a determinate spikelet pattern with $100 \%$ normal spikelets (Figure 2D). A total of 16 RILs expressed an indeterminate spikelet pattern with no variable expressivity, presenting 100\% multiflorous spikelets (Figure 2E). The remaining 69 RILs expressed variable expressivity, in which eight RILs presented type A mosaic and 61 RILs presented type B, C, or D mosaic (Figure 2F). As described for the 'U01B $x$ U006' population, no RILs in the 'UTau x U017' population showed 100\% mosaic spikelets.

A representative sample of 92 RILs from the 'U01B x U006' population was evaluated for two sowing dates during the 2014 growing season. Among the assessed RILs, 45 and 44 presented 100\% normal spikelets on the first and second sowing date, respectively (Figure $3 \mathrm{~A})$. In contrast, RILs expressing 100\% multiflorous spikelets were not observed on the first sowing date, whereas seven RILs were observed on the second sowing date (Figure 3B). These data show that no RILs presenting 100\% mosaic spikelets were present in both sowing dates. However, the number of RILs with $0 \%$ mosaic spikelets was lower on the first sowing date when compared with the second sowing date (Figure 3C).

For the 'UTau x U017' population, 90 RILs were evaluated on the same sowing dates, as described in the previous population during the 2014 growing season. From the evaluated RILs, 50 and 51 presented $100 \%$ normal spikelets on the first and second sowing date,

Genetics and Molecular Research 16 (1): gmr16019588 
respectively (Figure 4A). In this population, RILs expressing 100\% multiflorous spikelets were not found on the first sowing date. This result was consistent with that verified for the ' $\mathrm{U} 01 \mathrm{~B} \mathrm{x}$ U006' population. On the second sowing date, 14 RILs expressed 100\% multiflorous spikelets (Figure 4B). Considering RILs with variable expressivity for the multiflorous spikelet trait, only one RIL expressed $100 \%$ mosaic spikelets on the first sowing date, and this phenotype was not observed among the evaluated RILs on the second sowing date (Figure 4C). The number of RILs without mosaic spikelets was lower on the first sowing date compared with that on the second sowing date.

A

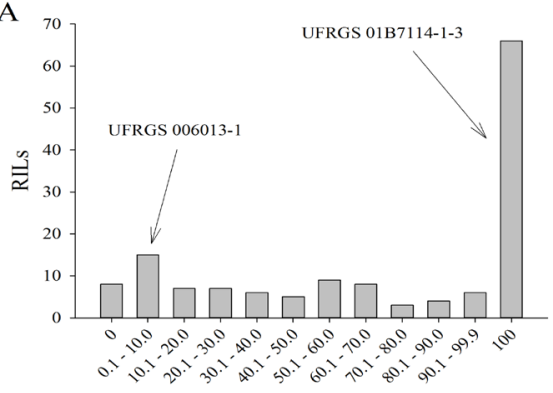

Normal (\%)

$$
\text { B }
$$

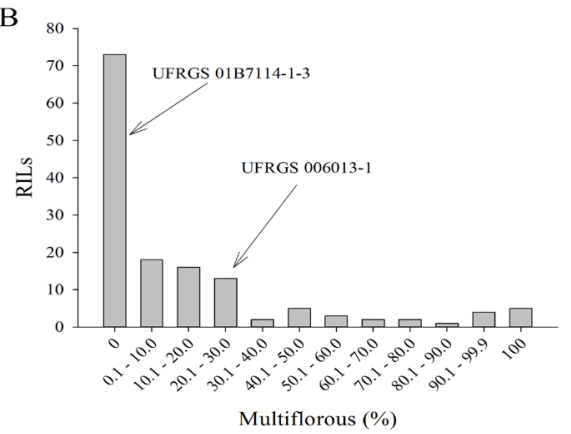

$\mathrm{C}$

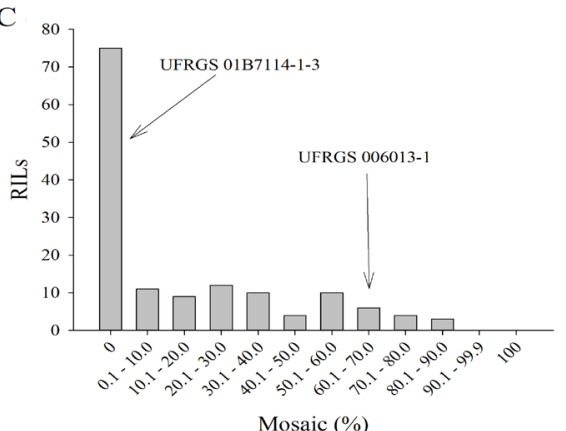

D
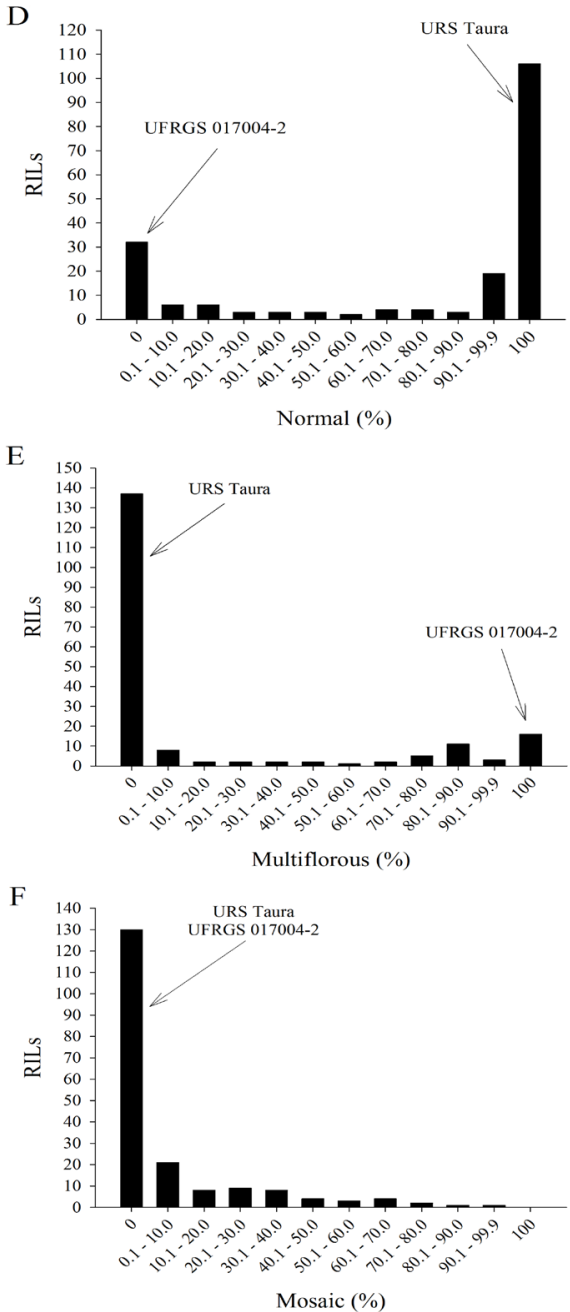

Figure 2. Multiflorous spikelet screening from two oat populations evaluated under field conditions in the growing season of 2013. Means of parental lines tested adjacent to recombinant inbred oat lines (RILs) are indicated with arrows. A. Normal spikelet; B. multiflorous spikelet; and C. mosaic spikelet observed among RILs from the 'UFRGS 01B7114-1-3 x UFRGS 006013-1' population. D. Normal spikelet; E. multiflorous spikelet; and F. mosaic spikelet observed among RILs from the 'URS Taura x UFRGS 017004-2' population.

Genetics and Molecular Research 16 (1): gmr16019588 

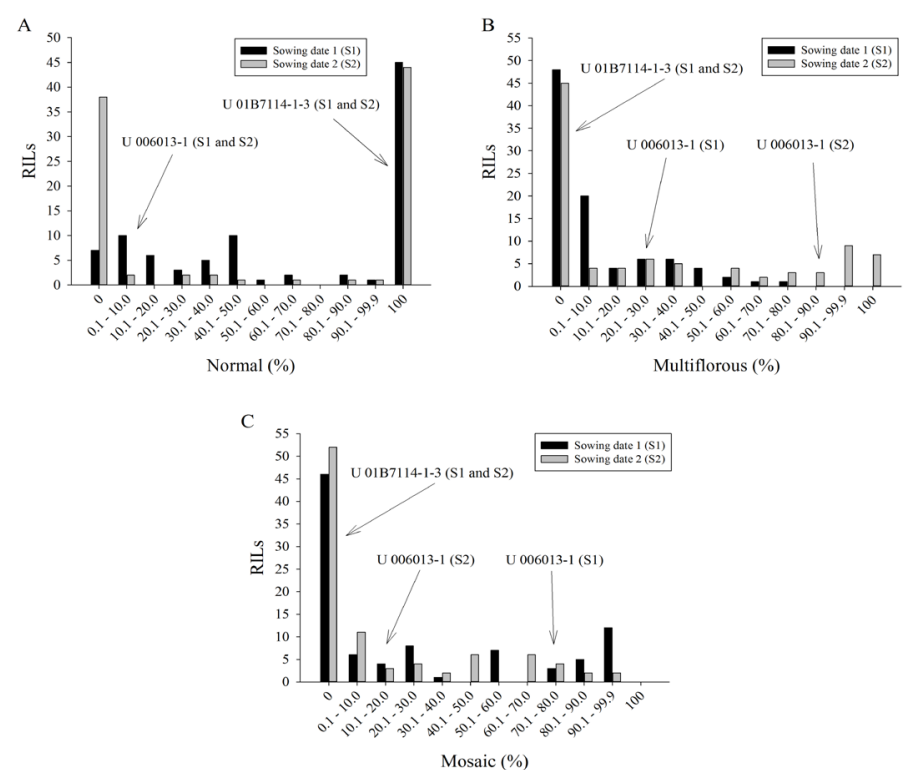

Figure 3. Multiflorous spikelet screening from the oat population 'UFRGS 01B7114-1-3 x UFRGS 0060131 ' evaluated under field conditions on two sowing dates in 2014. Means of parental lines tested adjacent to recombinant inbred oat lines (RILs) are indicated with arrows. Black bars represent phenotypic data collected on the first sowing date, while gray bars represent phenotypic data collected on the second sowing date. A. Normal spikelet; B. multiflorous spikelet; and C. mosaic spikelet observed among RILs.
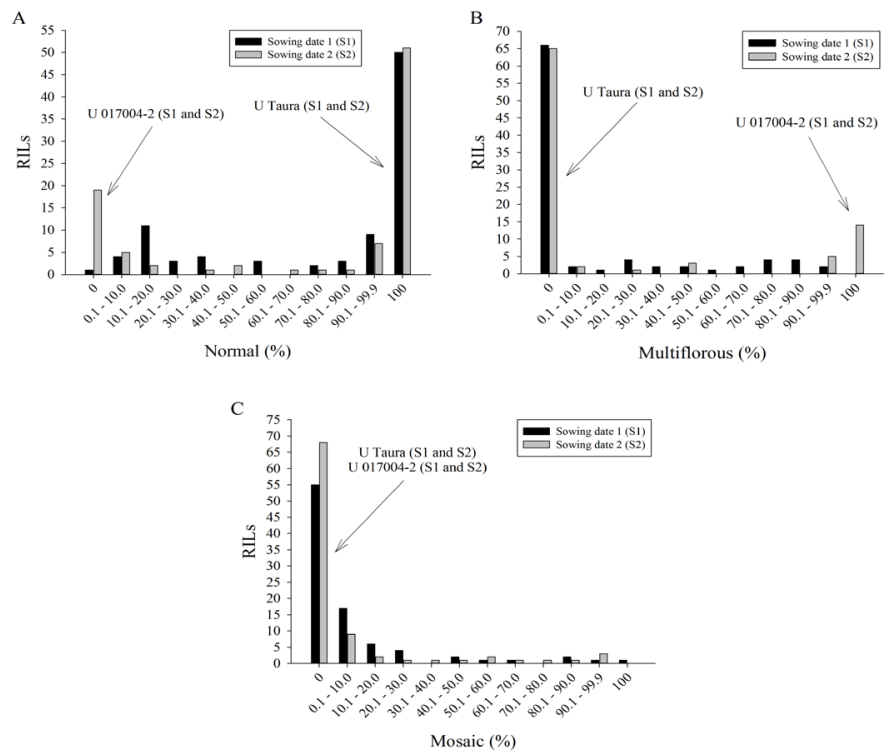

Figure 4. Multiflorous spikelet screening in the oat population 'URS Taura x UFRGS 017004-2' evaluated under field conditions on two sowing dates in 2014. Means of parental lines tested adjacent to recombinant inbred oat lines (RILs) are indicated with arrows. Black bars represent phenotypic data collected on the first sowing date, while gray bars represent phenotypic data collected on the second sowing date. A. Normal spikelet; B. multiflorous spikelet; and C. mosaic spikelet observed among RILs.

Genetics and Molecular Research 16 (1): gmr16019588 
The variance analyses indicated the presence of a strong genotype-by-sowing date interaction for the multiflorous spikelet trait, in both populations 'U01B x U006' and 'UTau x U017' (Table 1). These results suggest that the expression of normal, multiflorous, and mosaic spikelets was influenced by differences in environmental conditions between sowing dates. For the 'U01B x U006' population, there was a 21\% increase and an average 10 and $11 \%$ decrease, on the second sowing date for multiflorous, mosaic, and normal spikelets relative to the first sowing date, respectively (Table 1). For the 'UTau x U017' population, the second sowing date produced an increase of $9 \%$ and an average decrease of 1and $8 \%$ for multiflorous, mosaic, and normal spikelets relative to the first sowing date, respectively (Table 1).

Table 1. Summary of variance analyses for the multiflorous spikelet trait in oat.

\begin{tabular}{|c|c|c|c|c|}
\hline \multirow[t]{2}{*}{ Cause of variation } & \multirow[t]{2}{*}{ d.f. } & \multicolumn{3}{|c|}{ Mean square } \\
\hline & & MULTS (\%) & MOSS (\%) & NORS (\%) \\
\hline \multicolumn{5}{|c|}{ UFRGS 01B7114-1-3 x UFRGS 006030-1 } \\
\hline Block/Sowing date & 2 & 1014.92 & 914.38 & 98.72 \\
\hline Genotype (G) & 91 & $2917.48^{* *}$ & $3765.93 * *$ & $7783.76^{* *}$ \\
\hline Sowing date (SD) & 1 & $36,880.04 *$ & $8388.72^{\mathrm{ns}}$ & $10,111.52 * *$ \\
\hline Gx SD & 91 & $676.72 * *$ & $452.74 * *$ & $302.29 * *$ \\
\hline Experimental error & 182 & 112.92 & 172.95 & 179.94 \\
\hline Average 1st SD & - & 10 & 27 & 63 \\
\hline Average 2nd SD & - & 31 & 17 & 52 \\
\hline Response to late SD & - & $+21 \%$ & $-10 \%$ & $-11 \%$ \\
\hline \multicolumn{5}{|c|}{ URS Taura x UFRGS 017004-2 } \\
\hline Block/Sowing date & 2 & 60.51 & 25.78 & 59.08 \\
\hline Genotype (G) & 89 & $4623.61^{* *}$ & $1974.45^{* *}$ & $6391.15 * *$ \\
\hline Sowing date (SD) & 1 & $6258.34^{* *}$ & $52.90^{\mathrm{ns}}$ & $5152.90 *$ \\
\hline Gx SD & 89 & $335.93 * *$ & $167.16^{* *}$ & $242.83 * *$ \\
\hline Experimental error & 178 & 78.30 & 87.05 & 70.43 \\
\hline Average 1st SD & - & 14 & 10 & 76 \\
\hline Average 2nd SD & - & 23 & 9 & 68 \\
\hline Response to late SD & - & +9 & $-1 \%$ & $-8 \%$ \\
\hline
\end{tabular}

d.f. $=$ degrees of freedom; MULTS $=$ multiflorous spikelet; MOSS $=$ mosaic spikelet; NORS $=$ normal spikelet .

\section{Genetics of the multiflorous spikelet trait}

The major gene model controlling the spikelet growth pattern (determinate and indeterminate), was tested in the first step of the genetic analysis. For the 'U01B x U006' genetic population evaluated in 2013, 78 RILs were grouped as having an indeterminate spikelet growth pattern, whereas 66 RILs were grouped as having a determinate spikelet growth pattern. The chi-square test value was $1.0(\mathrm{P}=0.32)$, suggesting that the 'one-gene' hypothesis should not be rejected (Table 2).

Table 2. Chi-square test of observed and expected frequencies of 'one major gene' controlling the spikelet growth pattern in two oat genetic populations evaluated in 2013.

\begin{tabular}{l|l|c|c|c|c}
\hline Genetic population & Group & $\mathrm{F}_{\mathrm{obs}}{ }^{\dagger}$ & $\mathrm{F}_{\mathrm{exp}}^{\S}$ & $\chi^{2}$ & $\mathrm{P}^{*}$ \\
\hline \multirow{2}{*}{ UFRGS 01B7114-1-3 x UFRGS 006013-1 } & Indeterminate & 78.0 & 72.0 & \multirow{2}{*}{0.00} & \\
\cline { 2 - 5 } & Determinate & 66.0 & 72.0 & & \\
\hline \multirow{2}{*}{ URS Taura x UFRGS 017004-2 } & Indeterminate & 85.0 & 95.5 & \multirow{2}{*}{2.31} & \multirow{2}{*}{0.13} \\
\cline { 2 - 4 } & Determinate & 106.0 & 95.5 & & \\
\hline
\end{tabular}

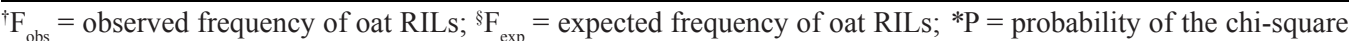
$\left(\chi^{2}\right)$ test value, considering one degree of freedom.

Genetics and Molecular Research 16 (1): gmr16019588 
For the 'UTau $\mathrm{x}$ U017' genetic population, 85 RILs were grouped as having an indeterminate spikelet growth pattern, and 106 RILs were grouped as having a determinate spikelet growth pattern. The value obtained by chi-square test was $2.31(\mathrm{P}=0.13)$. Similar to the previous population, the observed data for this population adjusted well with the genetic hypothesis of one major gene controlling the spikelet growth pattern in hexaploid oat (Table 2).

A representative number of RILs developed from the 'U01B x U006' and 'UTau x U017' crosses was evaluated from two different sowing dates in 2014. For the 'U01B x U006' genetic population, 47 RILs were grouped as indeterminate and 45 RILs were grouped as determinate on the first sowing date, while 48 and 44 RILs were grouped as indeterminate and determinate on the second sowing date, respectively. Based on these data, the value obtained by chi-square test was $0.04(\mathrm{P}=0.83)$ on the first sowing date and $0.17(\mathrm{P}=0.68)$ on the second sowing date (Table 3). The hypothesis of one major gene controlling the spikelet growth pattern cannot be rejected for this population from each sowing date.

Table 3. Chi-square test of observed and expected frequencies of 'one major gene controlling spikelet growth pattern' in two oat genetic populations evaluated for two sowing dates over the growing season of 2014.

\begin{tabular}{|c|c|c|c|c|c|c|}
\hline Genetic population & Sowing date & Group & $\mathrm{F}_{\mathrm{obs}}^{\dagger}$ & $\mathrm{F}_{\exp }{ }^{8}$ & $\chi^{2}$ & $\mathrm{P}^{*}$ \\
\hline \multirow[t]{4}{*}{ UFRGS 01B7114-1-3 x UFRGS 006013-1 } & \multirow[t]{2}{*}{ June 12th } & Indeterminate & 47 & 46 & \multirow[t]{2}{*}{0.04} & \multirow[t]{2}{*}{0.83} \\
\hline & & Determinate & 45 & 46 & & \\
\hline & \multirow[t]{2}{*}{ July 4th } & Indeterminate & 48 & 46 & \multirow[t]{2}{*}{0.17} & \multirow[t]{2}{*}{0.68} \\
\hline & & Determinate & 44 & 46 & & \\
\hline \multirow[t]{4}{*}{ URS Taura x UFRGS 017004-2 } & \multirow[t]{2}{*}{ June 12th } & Indeterminate & 40 & 45 & \multirow[t]{2}{*}{1.11} & \multirow[t]{2}{*}{0.29} \\
\hline & & Determinate & 50 & 45 & & \\
\hline & \multirow[t]{2}{*}{ July 4th } & Indeterminate & 39 & 45 & \multirow[t]{2}{*}{1.60} & \multirow[t]{2}{*}{0.21} \\
\hline & & Determinate & 51 & 45 & & \\
\hline
\end{tabular}

${ }^{\dagger} \mathrm{F}_{\mathrm{obs}}=$ observed frequency of oat RILs; ${ }^{\S} \mathrm{F}_{\text {exp }}=$ expected frequency of oat RILs; ${ }^{*} \mathrm{P}=$ probability of the chi-square $\left(\chi^{2}\right)$ test, considering one degree of freedom.

For the 'UTau $\mathrm{x}$ U017' genetic population, the frequency of RILs grouped as indeterminate and determinate according to multiflorous spikelet expression was 40 and 50, respectively, on the first sowing date. On the second sowing date, 39 RILs were grouped as indeterminate, while 51 RILs were grouped as determinate. The value obtained by chi-square test was $1.11(\mathrm{P}=0.29)$ on the first sowing date and $1.60(\mathrm{P}=0.21)$ on the second sowing date (Table 3). The observed results for this population also indicate that the 'one major gene' hypothesis cannot be rejected. Based on the phenotypic variation observed, our results suggest that regardless of year and sowing date, one major gene is closely associated with the spikelet growth pattern in both populations of oat RILs evaluated in this study.

In the second step of the genetic analyses, the presence of modifying genes interacting with a major gene was investigated. The objective of these analyses was to explain the variable expressivity observed for the trait among RILs according to their spikelet growth pattern. For the 'U01B x U006' genetic population evaluated in 2013, five RILs were grouped as multiflorous (100\% multiflorous spikelets), 73 RILs were grouped as having variable expressivity (type A, B, C, or D mosaic spikelets), and 66 RILs were grouped as normal (100\% normal spikelets). Considering the genetic hypothesis that one major gene and two modifying genes control the multiflorous spikelet trait, the value obtained by chi-square test was $16.57(\mathrm{P}=0.00)$ (Table 4). This result did not fit well with the genetic hypothesis and cannot be accepted. When the genetic hypothesis of 'one major gene and three modifying genes' was analyzed, the value obtained by chi-square test was $3.86(\mathrm{P}=0.15)$ (Table 4$)$. This indicates that the action of one 
major gene and three modifying genes controlling the multiflorous spikelet trait in the 'U01B x U006' population cannot be rejected.

Table 4. Chi-square test of the observed and expected frequencies for the multiflorous spikelet trait in two oat genetic populations evaluated in 2013.

\begin{tabular}{|c|c|c|c|c|c|}
\hline Genetic population & Group & $\mathrm{Fobs}^{\dagger}$ & $\mathrm{F}_{\exp } \S$ & $\chi^{2}$ & $\mathrm{P}^{*}$ \\
\hline \multicolumn{6}{|c|}{ Genetic model - one major gene and two modifying genes } \\
\hline \multirow[t]{3}{*}{ UFRGS 01B7114-1-3 x UFRGS 006013-1 } & Multiflorous & 5.0 & 18.0 & \multirow[t]{3}{*}{16.57} & \multirow[t]{3}{*}{0.00} \\
\hline & Variable expressivity & 73.0 & 54.0 & & \\
\hline & Normal & 66.0 & 72.0 & & \\
\hline \multirow[t]{3}{*}{ URS Taura $x$ UFRGS 017004-2 } & Multiflorous & 16.0 & 23.9 & \multirow[t]{3}{*}{3.85} & \multirow[t]{3}{*}{0.15} \\
\hline & Variable expressivity & 69.0 & 71.6 & & \\
\hline & Normal & 106.0 & 95.5 & & \\
\hline \multicolumn{6}{|c|}{ Genetic model - one major gene and three modifying genes } \\
\hline \multirow[t]{3}{*}{ UFRGS 01B7114-1-3 x UFRGS 006013-1 } & Multiflorous & 5.0 & 9.0 & \multirow[t]{3}{*}{3.86} & \multirow[t]{3}{*}{0.15} \\
\hline & Variable expressivity & 73.0 & 63.0 & & \\
\hline & Normal & 66.0 & 72.0 & & \\
\hline \multirow[t]{3}{*}{ URS Taura x UFRGS 017004-2 } & Multiflorous & 16.0 & 11.9 & \multirow[t]{3}{*}{5.07} & \multirow[t]{3}{*}{0.08} \\
\hline & Variable expressivity & 69.0 & 83.6 & & \\
\hline & Normal & 106.0 & 95.5 & & \\
\hline
\end{tabular}

${ }^{\dagger} \mathrm{F}_{\mathrm{obs}}=$ observed frequency of oat RILs for the multiflorous spikelet trait; ${ }^{\S} \mathrm{F}_{\text {exp }}=$ expected frequency of oat RILs; $* \mathrm{P}=$ probability of the chi-square test value $\left(\mathrm{c}^{2}\right)$, considering two degrees of freedom.

For the 'UTau x U017' population evaluated in 2013, 16 RILs were grouped as multiflorous, 69 RILs were grouped as having variable expressivity, and 106 RILs were grouped as normal. The genetic hypothesis of 'one major gene and two modifying genes' was analyzed and a chi-square test value of $3.85(\mathrm{P}=0.15)$ was calculated (Table 4). The hypothesis stating that one major gene and two modifying genes control the multiflorous spikelet trait cannot be rejected in this population. For the genetic hypothesis of 'one major gene and three modifying genes', the chi-square test value was $5.07(\mathrm{P}=0.08)$ (Table 4). This also indicates that the hypothesis of one major gene and three modifying genes controlling the multiflorous spikelet trait cannot be rejected. Although both genetic hypotheses have not been rejected, the 'two modifying genes' hypothesis best fit the data in this population. Conversely, the involvement of two modifying genes diverged from the previous population, 'U01B x U006'.

The involvement of modifying genes controlling the multiflorous spikelet trait was also analyzed in a representative number of RILs from each genetic population on two different sowing dates of 2014. For the 'U01B x U006' population evaluated on the first sowing date, zero, 47, and 45 RILs were grouped as having multiflorous spikelets, variable expressivity, and normal spikelets, respectively (Table 5). On the second sowing date, 7 , 41 , and 44 RILs were grouped as having multiflorous spikelets, variable expressivity, and normal spikelets, respectively (Table 5). Based on these observed data, the chi-square test values were $16.05(\mathrm{P}=0.00)$ and $6.90(\mathrm{P}=0.03)$ for the genetic hypotheses of 'one major gene and two or three modifying genes', respectively, on the first sowing date. On the second sowing date, the chi-square test values were $3.07(\mathrm{P}=0.22)$ and $0.37(\mathrm{P}=0.83)$ for the genetic hypotheses of 'one major gene and two or three modifying genes', respectively (Table 5). Based on our observed results, the genetic hypotheses of 'one major gene and two or three modifying genes' cannot be accepted for the first sowing date. Conversely, neither genetic hypotheses of 'one major gene plus two or three modifying genes' can be rejected for the second sowing date. 
Table 5. Chi-square test of the observed and expected frequencies in two oat genetic populations evaluated for the multiflorous spikelet trait on two sowing dates over the growing season of 2014.

\begin{tabular}{|c|c|c|c|c|c|c|}
\hline Genetic population & Sowing date & Group & $\mathrm{Fobs}^{\dagger}$ & $F_{\text {exp }}{ }^{\S}$ & $\chi^{2}$ & $\mathrm{P}^{*}$ \\
\hline \multicolumn{7}{|c|}{ Genetic model - one major gene and two modifying genes } \\
\hline \multirow[t]{6}{*}{ UFRGS 01B7114-1-3 x UFRGS 006013-1 } & \multirow[t]{3}{*}{ June 12th } & Multiflorous & 0.0 & 11.5 & \multirow[t]{3}{*}{16.05} & \multirow[t]{3}{*}{0.00} \\
\hline & & Variable expressivity & 47.0 & 34.5 & & \\
\hline & & Normal & 45.0 & 46.0 & & \\
\hline & \multirow[t]{3}{*}{ July 4th } & Multiflorous & 7.0 & 11.5 & \multirow[t]{3}{*}{3.07} & \multirow[t]{3}{*}{0.22} \\
\hline & & Variable expressivity & 41.0 & 34.5 & & \\
\hline & & Normal & 44.0 & 46.0 & & \\
\hline \multirow[t]{6}{*}{ URS Taura $x$ UFRGS 017004-2 } & \multirow[t]{3}{*}{ June 12th } & Multiflorous & 1.0 & 11.2 & \multirow[t]{3}{*}{10.71} & \multirow[t]{3}{*}{0.00} \\
\hline & & Variable expressivity & 39.0 & 33.8 & & \\
\hline & & Normal & 50.0 & 45.0 & & \\
\hline & \multirow[t]{3}{*}{ July 4th } & Multiflorous & 14.0 & 11.2 & \multirow[t]{3}{*}{3.74} & \multirow[t]{3}{*}{0.15} \\
\hline & & Variable expressivity & 25.0 & 33.8 & & \\
\hline & & Normal & 51.0 & 45.0 & & \\
\hline \multicolumn{7}{|c|}{ Genetic model - one major gene and three modifying genes } \\
\hline \multirow[t]{6}{*}{ UFRGS 01B7114-1-3 x UFRGS 006013-1 } & \multirow[t]{3}{*}{ June 12th } & Multiflorous & 0.0 & 5.8 & \multirow[t]{3}{*}{6.90} & \multirow[t]{3}{*}{0.03} \\
\hline & & Variable expressivity & 47.0 & 40.2 & & \\
\hline & & Normal & 45.0 & 46.0 & & \\
\hline & \multirow[t]{3}{*}{ July 4th } & Multiflorous & 7.0 & 5.8 & \multirow[t]{3}{*}{0.37} & \multirow[t]{3}{*}{0.83} \\
\hline & & Variable expressivity & 41.0 & 40.2 & & \\
\hline & & Normal & 44.0 & 46.0 & & \\
\hline \multirow[t]{6}{*}{ URS Taura $x$ UFRGS 017004-2 } & \multirow[t]{3}{*}{ June 12th } & Multiflorous & 1.0 & 5.6 & \multirow[t]{3}{*}{4.36} & \multirow[t]{3}{*}{0.11} \\
\hline & & Variable expressivity & 39.0 & 39.4 & & \\
\hline & & Normal & 50.0 & 45.0 & & \\
\hline & \multirow[t]{3}{*}{ July 4th } & Multiflorous & 14.0 & 5.6 & \multirow[t]{3}{*}{18.52} & \multirow[t]{3}{*}{0.00} \\
\hline & & Variable expressivity & 25.0 & 39.4 & & \\
\hline & & Normal & 51.0 & 45.0 & & \\
\hline
\end{tabular}

${ }^{\dagger} \mathrm{F}_{\mathrm{obs}}=$ observed frequency of oat RILs for the multiflorous spikelet trait; ${ }^{\S} \mathrm{F}_{\mathrm{exp}}=$ expected frequency of oat RILs; $* \mathrm{P}=$ probability of the calculated chi-square value $\left(\chi^{2}\right)$, considering two degrees of freedom.

For the 'UTau x U017' population evaluated on the first sowing date, one, 39, and 50 RILs were grouped as having multiflorous spikelets, variable expressivity, and normal spikelets, respectively (Table 5). On the second sowing date, 14, 25, and 51 RILs were grouped as having multiflorous spikelets, variable expressivity, and normal spikelets, respectively (Table 5). On the first sowing date, the chi-square test values were $10.71(\mathrm{P}=0.00)$ and $4.36(\mathrm{P}=0.11)$ for the genetic hypotheses of 'one major gene and two or three modifying genes', respectively. For the second sowing date, the chi-square test values were $3.74(\mathrm{P}=0.15)$ and $18.52(\mathrm{P}=0.00)$ for the genetic hypotheses of 'one major gene and two or three modifying genes', respectively (Table 5). These results suggest that the action of three modifying genes on the major gene cannot be rejected in the 'UTau x U017' population, for the first sowing date. However, the environmental conditions present on the second sowing date restricted the action of one of these modifying genes, suggesting that their action is highly influenced by crop environments.

\section{Cloning of candidate gene sequences from contrasting genotypes}

Genomic sequences from oat with similarity to the AP2 gene family in grasses were isolated in the parental lines URS Taura and UFRGS 017004-2, using the 'AP2.7' primer pair. Two distinct sequences for both parental lines, presented here as 'seqA' and 'seqB', were isolated. These sequences showed high nucleotide similarity between the parental lines. Alignment of the 'seqA' sequence revealed high similarity to the $A P 2$ gene from $B$. distachyon. The highest similarity between sequences derived from oat and $B$. distachyon was found in a region corresponding to the fifth exon of the $A P 2$ gene. However, this region was represented by a short segment about 20 nucleotides in length (Figure 5 ).

Genetics and Molecular Research 16 (1): gmr16019588 


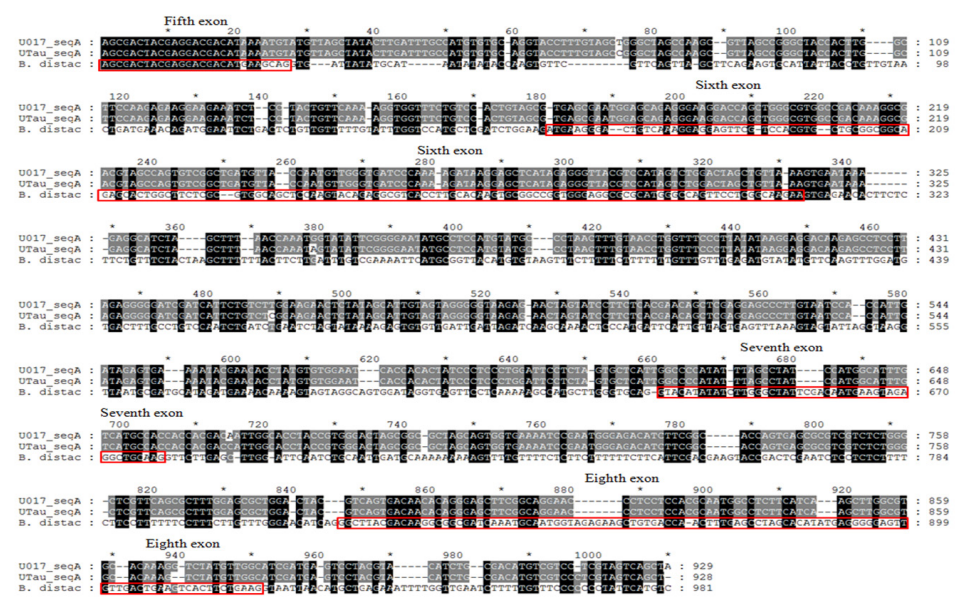

Figure 5. Partial alignment of oat and Brachypodium distachyon sequences corresponding to the $A P 2$ gene. Exon sequences of the $A P 2$ gene from $B$. distachyon are highlighted with red boxes. Legend: U017_seqA = nucleotide sequence from the parental line UFRGS 017004-2; UTau_seqA = nucleotide sequence from the parental line URS Taura; and B. distac $=$ nucleotide sequence from B. distachyon (accession XM_010233483.1).

Cloned 'seqA' sequences corresponding to the $A P 2$ gene shared nucleotide similarity with a non-coding microRNA gene, miR172a, from B. distachyon. Moreover, a putative ORF was identified downstream to the pairing region of miR172a with the oat sequences. The putative protein starts at position 643 and extends to position 931, producing a chain of 96 amino acids. Four SNP markers and three base insertions or deletions (indels) were identified in the cloned DNA segment from the parental lines URS Taura and UFRGS 017004-2. These polymorphisms were located at positions 74, 353, 460, 671, 872, 921, and 934 (Figure 6). Of these, the SNP marker located at position 671 is within the ORF and represents a substitution of the nucleotide adenine in UFRGS 017004-1 for a cytosine in URS Taura (Figure 6).

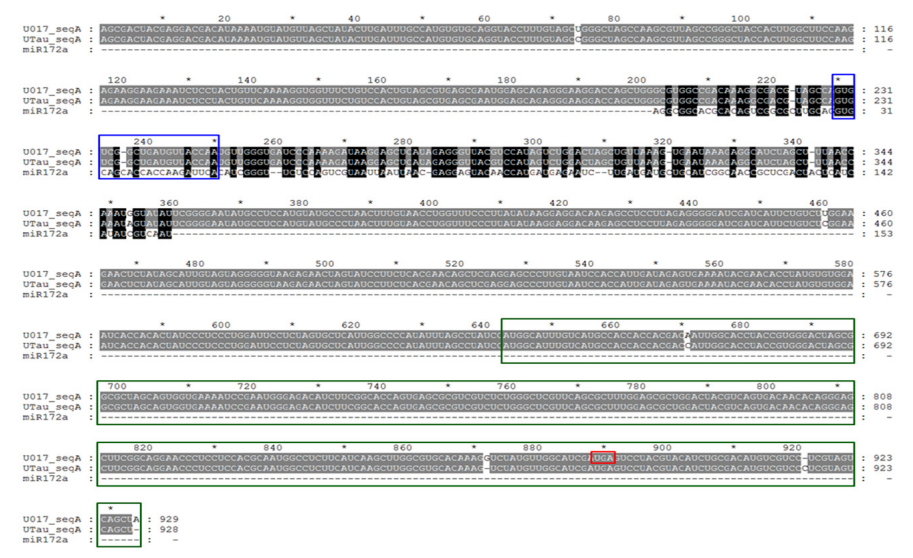

Figure 6. Alignment of oat mRNA sequences of the $A P 2$ gene and identification of a putative matching site for miR172a from Brachypodium distachyon. The matching site between miR172 and mRNA sequences from oat is highlighted with a blue box. Green and red boxes represent a putative open reading frame and a premature stop codon within the sequence of UFRGS 017004-2, respectively.

Genetics and Molecular Research 16 (1): gmr16019588 
For the indel at position 872 , UFRGS $017004-2$ possesses a guanine, whereas no nucleotide is assigned for URS Taura. For the indel at position 921, URS Taura has a cytosine, whereas no nucleotide is assigned for UFRGS 017004-2 (Figure 6). The occurrence of SNPs and/or indels changed the amino acid sequence of the parental lines URS Taura and UFRGS 017004-2. The presence of adenine at position 671 specifies the incorporation of glutamine in UFRGS 017004-2, whereas the presence of cytosine in this position specifies the incorporation of proline in URS Taura (Figure 7A).
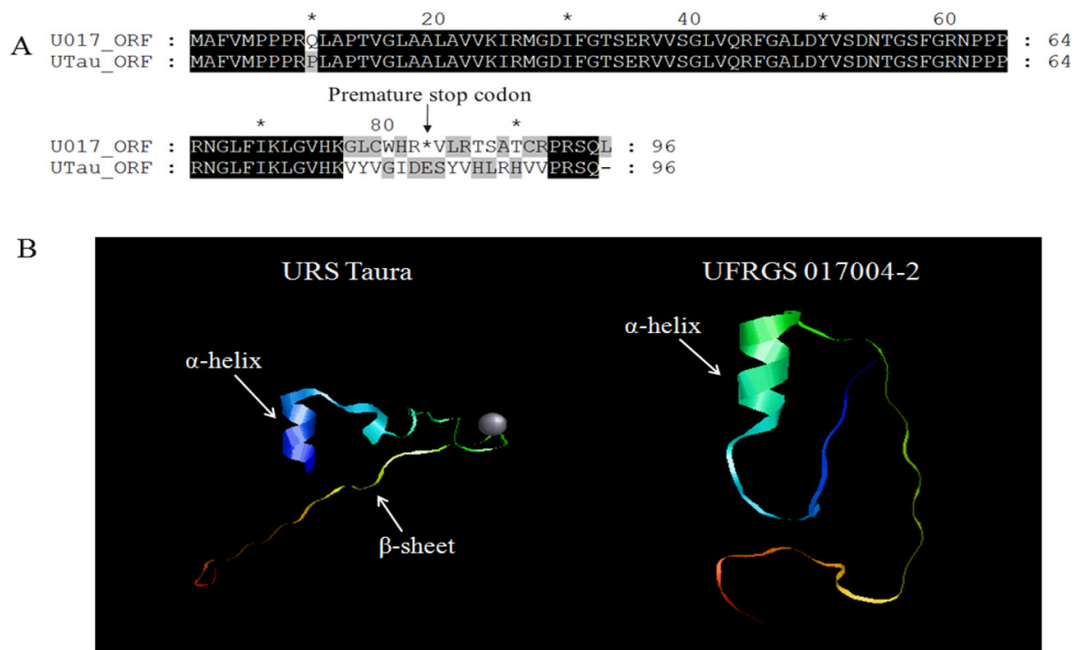

Figure 7. Amino acid sequences and the structure of AP2-like protein in hexaploid oat. A. Alignment of amino acid sequences derived from the parental lines UFRGS 017004-2 and URS Taura. B. Three-dimensional structure of AP2-like protein derived from the parental lines URS Taura and UFRGS 017004-2 predicted by the SWISSMODEL modeling server.

The amino acid sequence produced by URS Taura and UFRGS 017004-2 became fully distinct (Figure 7A) from the indel located at position 872 (Figure 6). The occurrence of this indel caused the premature interruption of the amino acid sequence of UFRGS 017004-2 due to the translation stop codon UGA (Opal), which is located between positions 889 and 891 (Figure 6), and at position 83 (represented by an asterisk in Figure 7A). Thus, it is likely that the protein synthesized by UFRGS 017004-2 is truncated in comparison to that synthesized by URS Taura. The absence of guanine at position 872 prevents the occurrence of this premature stop codon in URS Taura (Figure 6). To investigate the organization of the protein synthesized by the $A P 2$ gene in oat, a three-dimensional structure of the URS Taura and UFRGS 0170042 proteins were predicted (Figure 7B). These results indicate that a different structural motif can be found in the predicted protein of each parental line. The predicted protein for URS Taura showed an $\alpha+\beta$ domain, containing the secondary structures ' $\alpha$-helix' and ' $\beta$-sheet'. Furthermore, the three-dimensional structure of the URS Taura protein reveals the association of a $\mathrm{Ca}^{+2}$ monomer. The predicted protein for UFRGS 017004-2 contains an $\alpha$ domain only and is composed of an ' $\alpha$-helix' (Figure 7B).

The 'seqB' sequence, derived from URS Taura and UFRGS 017004-2, cloned and sequenced in both lines, exhibited nucleotide similarity to the $A P 2$ gene from $B$. distachyon, 
barley, and wheat (Figure 8). Considering the alignment of sequences from URS Taura and UFRGS 017004-2, two SNPs and five indels were identified. The parental line UFRGS 0170042 possesses guanine at positions 178 and 615, whereas URS Taura possesses adenine at the same positions. At positions 861 and 1005, URS Taura possesses thymine and cytosine, respectively, whereas UFRGS 017004-2 possesses no nucleotides at the same positions. In the same way, URS Taura possesses guanine at positions 943 and 959, while UFRGS 017004-2 possesses no nucleotides at these positions. Conversely, UFRGS 017004-2 possesses a cytosine at position 997, whereas URS Taura possesses no nucleotide at this position (Figure 8).

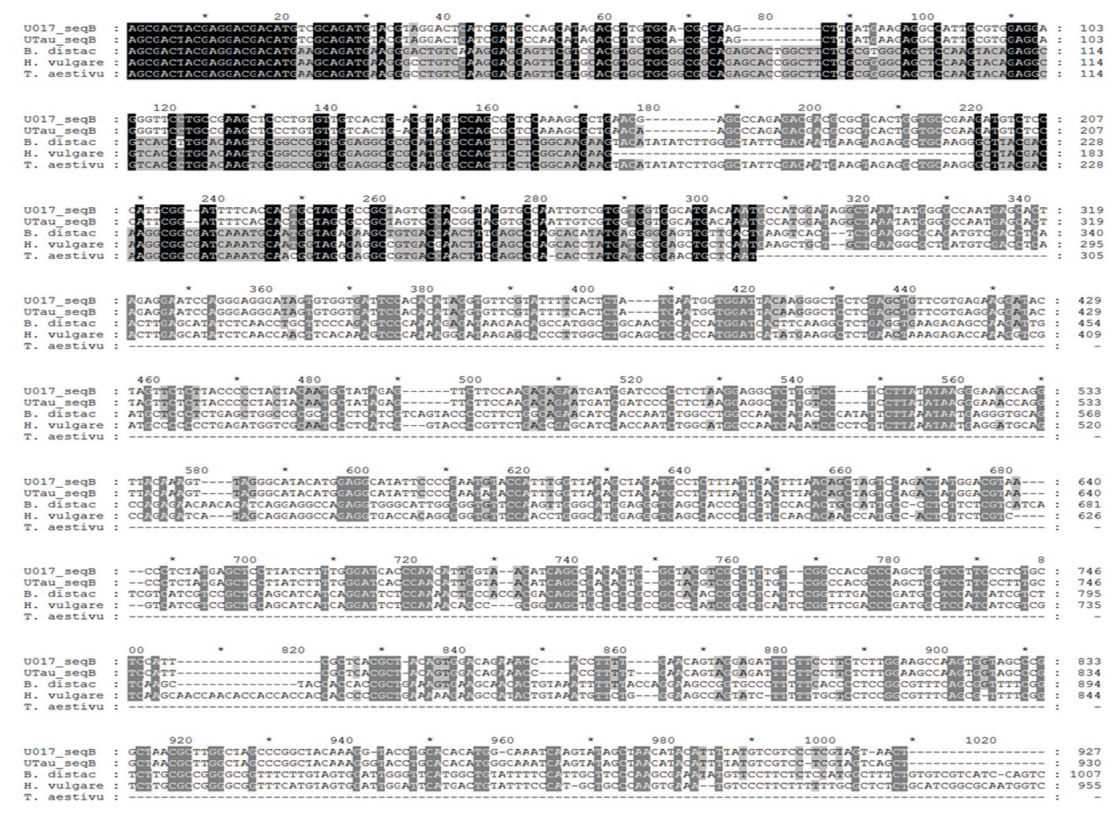

Figure 8. Partial alignment of oat, Brachypodium distachyon, barley, and wheat sequences corresponding to a member of the AP2 gene family. Legend: U017_seqB = nucleotide sequence from the parental line UFRGS 0170042; UTau_seqB $=$ nucleotide sequence from the parental line URS Taura; B. distac $=$ nucleotide sequence from $B$. distachyon (accession XM_010233483.1); H. vulgare = nucleotide sequence from barley (accession AK370055.1); and T. aestivu $=$ nucleotide sequence from wheat (accession AJ577368.1).

\section{DISCUSSION}

The formation of multiflorous spikelets was similar for both populations of oat RILs, 'U01B x U006' and 'UTau x U017', evaluated in 2013 and 2014. However, an increased formation of multiflorous spikelets was observed in the second sowing date in 2014, and this pattern was similar for both populations (Table 1, Figure 3, and Figure 4). The increased number of multiflorous spikelets was associated with changes in environmental conditions between sowing dates. On the second sowing date, higher mean daily maximum temperatures were recorded relative to those on the first sowing date (Figure S1). However, day-length was also longer throughout the stages of plant development on the second sowing date. Based on these results, it is important to note that under higher temperature and longer day-length conditions, as occurred on the second sowing date, variable expressivity of the multiflorous 
spikelet trait was less pronounced among the evaluated RILs for both populations. This phenomenon can be demonstrated by the relatively large number of RILs expressing $100 \%$ multiflorous spikelets on the second sowing date (Figure 3 and Figure 4).

Variable expressivity, as occurs for the multiflorous spikelet trait in hexaploid oat, has also been reported for other grass species of high agricultural and economic interest. In rice, variable expressivity in fickle spikelet $1\left(f_{s p} l\right)$ mutants seems to be strongly influenced by environmental conditions, such as temperature. Rice mutant plants for the $f_{s p} 1$ gene display an increased number of floral spikelet organs (Suzuki et al., 2015). Although studies evaluating the effects of temperature on the formation of multiflorous spikelets are scarce in the literature, the association of temperature with the formation of naked grains has been observed in oat. When evaluating eight naked oat genotypes under three temperatures $\left(15^{\circ}, 20^{\circ}\right.$, and $\left.25^{\circ} \mathrm{C}\right)$, and controlled environmental conditions, Lawes and Boland (1974) identified increased formation of naked grains at $25^{\circ} \mathrm{C}$. These results were confirmed under field conditions, where the largest number of naked grains was obtained from the late sowing date with higher temperatures.

Genetic factors responsible for determining the formation of multiflorous spikelets are not fully understood in oat. However, these factors should act in a coordinated manner in response to temperature changes (Lawes and Boland, 1974). Under conditions of high temperatures, it is likely that the spikelet meristem is not switched off, allowing the formation of multiple florets in a single spikelet. In addition to temperature, other environmental signals must affect the formation of multiflorous spikelets in oat. In a study involving 10 naked oat genotypes evaluated in Cambridge, UK, in five sowing dates (February to June), Jenkins (1973) found that the expression of multiflorous spikelets was genotype-specific, and varied depending on the day-length. Most of the evaluated genotypes exhibited higher expression of the multiflorous spikelet trait in April, although for some of the genotypes the expression was optimized from February to June (Jenkins 1973). These results confirm a strong genotype-bysowing date interaction on the multiflorous spikelet trait in oat, consistent with the results of the present study. Similar results involving a significant genotype-by-sowing date interaction, such as the temperature effects, were verified in tetraploid and hexaploid wheat genotypes with multiflorous spikelets (Pennell and Halloran, 1984).

The parental lines with multiflorous spikelets responded differently to environmental changes occurring throughout plant development in the field. In both years and sowing dates, UFRGS 006013-1 presented variable expressivity (Figure 2 and Figure 3), while UFRGS 017004-2 presented complete expressivity for the multiflorous spikelet trait (Figure 2 and Figure 4). However, the variable expressivity observed for UFRGS 006013-1 differed between sowing dates, in which an increased number of multiflorous spikelets and a reduced number of mosaic spikelets was observed on the second sowing date (Figure 3). These results suggest that the environmental conditions present on the second sowing date contributed to the higher expression of the multiflorous spikelets in the parental line UFRGS 006013-1. In contrast, UFRGS 017004-2 showed 100\% multiflorous spikelets on both sowing dates, which were not influenced by environmental variations (Figure 4). The differences in stability observed between UFRGS 006013-1 and UFRGS 017004-2 when evaluated under the same conditions, demonstrate that environmental changes were not sufficient to explain the causes of phenotypic variations observed for the multiflorous spikelet trait. Therefore, these parental lines must possess different genetic/epigenetic factors that regulate the expression of key genes involved in metabolic pathways, culminating in the formation of multiflorous spikelets.

Genetic analyses performed in this study for the 'U01B x U006' and 'UTau x

Genetics and Molecular Research 16 (1): gmr16019588 
U017' genetic populations revealed that the action of one major gene ( $M f 1)$ is responsible for the determinate or indeterminate spikelet growth pattern, regardless of the year, sowing date, or genetic population (Tables 2 and 3). Thus, oat RILs carrying two dominant alleles of the major gene (homozygous dominant) should present an indeterminate spikelet growth pattern, while RILs carrying two recessive alleles of the major gene (homozygous recessive) should present a determinate spikelet growth pattern. The actions of the different alleles were established considering the involvement of modifying genes. Our results are consistent with the available literature, in which a large number of studies have indicated that the action of one major gene controls multiflorous spikelet formation (Caporn, 1918; Love and McRostie, 1919; Boland and Lawes, 1973; Kibite and Taylor, 1994; Cabral et al., 2000). Phenotypic screening for the multiflorous spikelet trait clearly demonstrated a 1:1 ratio, in which approximately $50 \%$ of the evaluated RILs for both genetic populations exhibited 100\% normal spikelets. Moreover, variable expressivity was observed among RILs presenting the indeterminate spikelet growing pattern.

To understand how this variable expressivity occurs in oat, genetic hypotheses implicating the interaction of two or three modifying genes with the major gene were tested (Tables 4 and 5). The genetic analyses in the present study indicated that variable expressivity depends of modifying genes and their allelic combination, which are highly regulated by the environment. For the 'U01B x U006' genetic population, variable expressivity was best explained by the presence of the $M f 1$ gene interacting with three modifying genes ( $M f 2, M f 3$, and $M f 4$ ) (Tables 4 and 5). Thus, RILs carrying homozygous dominant alleles for the $M f 1$ gene and all three modifying genes exhibited $100 \%$ multiflorous spikelets. In contrast, RILs exhibiting mosaic phenotypes (type A, B, C, and D mosaic) should have homozygous dominant alleles for the $M f I$ gene and homozygous recessive alleles for at least one of the modifying genes. Conversely, RILs exhibiting 100\% normal spikelets should have homozygous recessive alleles for the Mf1 gene, regardless of the combination of alleles for the $M f 2, M f 3$, and $M f 4$ genes.

For the 'UTau x U017' genetic population, variable expressivity of the multiflorous spikelet trait was best explained by the presence of the $M f 1$ gene and the $M f 2$ and $M f 3$ modifying genes (Tables 4 and 5). Thus, RILs showing 100\% multiflorous spikelets should possess homozygous dominant alleles for all three genes. In contrast, RILs showing mosaic phenotypes should possess homozygous dominant alleles for the $M f 1$ gene and homozygous recessive alleles for at least one of the $M f 2$ and $M f 3$ modifying genes. Conversely, RILs with $100 \%$ normal spikelets should possess homozygous recessive alleles for the Mfl gene, regardless of the alleles present for the $M f 2$ and $M f 3$ genes.

Although our results do not permit the full mechanism driving variable expressivity of the multiflorous spikelet trait in oat to be elucidated, several factors may be involved, including: i) differential expression of alleles for the $M f l$ gene and the modifying genes, which can be regulated by environmental signals, such as temperature and day-length, or by genetic factors involving specific transcription factors; ii) allelic variation of the genes controlling the multiflorous spikelet trait from different sub-genomes of the hexaploid oat; iii) the $M f l$ gene may be located at one end of the chromosome (telomere region), making its expression difficult; iv) the presence or absence of functional alleles for the modifying genes needed for the complete expression of multiflorous spikelets; and v) epigenetic mechanisms regulating gene expression, especially the action of non-coding small RNA molecules such as microRNAs.

One of the main challenges involved in elucidating the multiflorous spikelet trait in hexaploid oat is the identification of genetic polymorphisms in contrasting genotypes and their association with the phenotype. Among the candidate genes controlling multiflorous spikelet

Genetics and Molecular Research 16 (1): gmr16019588 
development in oat, those belonging to the ABCDE model of flowering time are noteworthy. These genes are responsible for the differentiation of floral parts into their characteristic structures and the determination of floral meristem identity. Based on available information in the literature, members of the AP2 gene family play an important role in determining either floral differentiation or meristem determination in many plant species (Chuck et al., 2002; Komatsu et al., 2003; Zhu et al., 2003; Chuck et al., 2008; Lee and An, 2012; Derbyshire and Byrne, 2013; Poursarebani et al., 2015). However, sequences of the $A P 2$ genes derived from oat are not available in the literature to date. In this study, sequences with similarity to the $A P 2$ genes were isolated and characterized for the first time in hexaploid oat (Figure 5 and Figure 8). These sequences are likely to be involved in controlling the multiflorous spikelet trait, since they clearly showed genetic polymorphisms between the lines UFRGS 017004-2 (multiflorous spikelets) and URS Taura (normal spikelets).

Alignment of the sequences U017_seqA and UTau_seqA identified an ORF with $82 \%$ similarity between amino acid sequences for the lines UFRGS 017004-2 and URS Taura (Figure 7A). Protein modeling revealed a different protein structure in the lines for the $A P 2$ gene candidate sequences (Figure 7B). This differentiated protein structure may be crucial for multiflorous spikelet development, since the biological function of a protein is directly linked to its structure. The occurrence of a premature stop codon in UFRGS 017004-2 leads to the production of a truncated protein by restricting the correct function of the $A P 2$ gene in this line. In addition, this change in protein structure may limit the interaction between $A P 2$ and $A G A M O U S(A G)$ gene products, resulting in a phenotype with multiflorous spikelets similar to the ag mutant plants from Arabidopsis thaliana (Yanofsky et al., 1990).

In $B$. distachyon, mutant plants for the more spikelets 1 (mos 1 ) gene, which is orthologous to the $A P 2$ gene from $A$. thaliana, had an increased number of axillary meristems produced from the inflorescence meristem relative to wild type plants. These axillary meristems developed as branches with the production of higher order spikelets (Derbyshire and Byrne, 2013). The MOS1 gene from $B$. distachyon determines spikelet meristem fate and the transition to terminal spikelet development. Recent studies have shown that the expression of $A P 2$ genes is altered in response to environmental changes. Expression of the CONSTANS $(C O)$ gene in $A$. thaliana is highly influenced by photoperiod stimuli, and polypeptide products encoded by this gene interact with $A P 2$ gene family members, which encoding transcriptional regulators (Zhang et al., 2015).

Another factor that determines the expression of some members of the AP2 gene family is their post-transcriptional regulation by miR172. This microRNA regulates the expression of $A P 2$ genes and, consequently, regulates the transition between developmental stages and specifies floral organ identity in different species (Chen, 2004; Chuck et al., 2007). U017_seqA and UTau_seqA possess a region of approximately 21 nucleotides that match well with the $m i R 172$ sequence from $B$. distachyon (Figure 6), suggesting that this genomic region may contain a binding site for miR172. A genetic polymorphism identified in codon 418 of the $Q$ gene from wheat, which is located in a miR172 binding site, can differentiate dominant and recessive alleles. In this sense, mutations in the miR172 binding site can define the $Q$ gene action in wheat, thus directly influencing spike architecture (Sormacheva et al., 2015).

Mature miR172 molecules from maize, produced from the transcription of the TASSELSEED4 (TS4) gene, act on the regulatory targets INDETERMINATE SPIKELET1 (IDS1) and SISTER OF INDETERMINATE SPIKELET1 (SID1) genes, which are members of the AP2 gene family. Maize mutant plants for the $t s 4$ gene altered the identity of the spikelet

Genetics and Molecular Research 16 (1): gmr16019588 
meristem, causing indeterminate branches to form (Chuck et al., 2007). In rice, mRNA levels of the OSIDS1 and SUPERNUMERARY BRACT (SNB) genes, which are orthologous to the $I D S 1$ and SIDIgenes from maize, were significantly reduced in plants over-expressing miR172 compared to wild-type plants (Chuck et al., 2008; Lee and An, 2012). The miR172 genes are highly conserved in many grass species (Axtell and Bartel, 2005), and appear to regulate key target genes that control flower/spikelet development. Furthermore, the expression of miR172 is regulated by environmental conditions including day length and temperature (Jung et al., 2007; Lee et al., 2010). In this sense, considering the results presented in the present study and in the literature, the hypothesis that variable expressivity for the multiflorous spikelet trait in oat is under epigenetic control cannot be rejected.

Considerable research is still needed to fully understand the genetic and molecular mechanisms affecting the multiflorous spikelet trait in oat. Evidence of the contribution exerted by environmental conditions on the modulation of the multiflorous spikelet trait expression in oat is provided. The genetic analyses reported in this study clearly demonstrate the action of the $M f 1$ gene in the evaluated RILs on two distinct spikelet growth patterns, determinate and indeterminate, regardless of the year, sowing date, or genetic population. The results also demonstrated that modifying genes play an important role in modulating the multiflorous spikelet trait in oat. These modifying genes interact with the major gene depending on the genetic background and crop environmental conditions. Genetic models involving modifying genes were extensively tested in this study. In this way, we were able to estimate with a high level of reliability, the action of two or three modifying genes, depending on the genetic background used. Coding sequences with high nucleotide similarity to the $A P 2$ gene were identified for the first time in hexaploid oat. Since the oat sequences for the $A P 2$ gene were isolated using information from other grass species, our results indicate that this gene could be conserved in the oat genome and represents a strong candidate of the Mfl gene. The genetic polymorphisms detected between the lines UFRGS 017004-2 and URS Taura represent valuable information to confirm the action of the $A P 2$ gene on the multiflorous spikelet trait. Our results provide a fundamental basis and information to assist in the development of future studies of the multiflorous spikelet trait in hexaploid oat.

\section{Conflicts of interest}

The authors declare no conflict of interest.

\section{ACKNOWLEDGMENTS}

The authors thank Conselho Nacional de Desenvolvimento Científico e Tecnológico $(\mathrm{CNPq})$ for providing financial support for this research and Coordenação de Aperfeiçoamento de Pessoal de Nível Superior (CAPES) for providing a scholarship for the first author.

\section{REFERENCES}

Altschul SF, Gish W, Miller W, Myers EW, et al. (1990). Basic local alignment search tool. J. Mol. Biol. 215: 403-410. http://dx.doi.org/10.1016/S0022-2836(05)80360-2

Axtell MJ and Bartel DP (2005). Antiquity of microRNAs and their targets in land plants. Plant Cell 17: 1658-1673. http:// dx.doi.org/10.1105/tpc.105.032185

Genetics and Molecular Research 16 (1): gmr16019588 
Boland P and Lawes DA (1973). The inheritance of the naked grain character in oats studied in a cross between the naked variety Caesar and the husked variety BO 1/11. Euphytica 22: 582-591. http://dx.doi.org/10.1007/BF00036659

Burrows VD (1986). Breeding oats for food and feed: conventional and new techniques and materials. In: Oats: chemistry and technology (Webster FH, ed.). American Association of Cereal Chemists, Saint Paul, 13-46.

Cabral CB, Milach SCK, Federizzi LC, Bothona CA, et al. (2000). Genetics of naked grain oats in crosses with Brazilian genotypes. Genet. Mol. Biol. 23: 851-854. http://dx.doi.org/10.1590/S1415-47572000000400025

Caporn AS (1918). The inheritance of tight and loose paleae in Avena nuda crosses. J. Genet. 7: 229-246. http://dx.doi. org/10.1007/BF02983548

Chen X (2004). A microRNA as a translational repressor of APETALA2 in Arabidopsis flower development. Science 303: 2022-2025. http://dx.doi.org/10.1126/science. 1088060

Chuck G, Muszynski M, Kellogg E, Hake S, et al. (2002). The control of spikelet meristem identity by the branched silkless1 gene in maize. Science 298: 1238-1241. http://dx.doi.org/10.1126/science.1076920

Chuck G, Meeley R, Irish E, Sakai H, et al. (2007). The maize tasselseed4 microRNA controls sex determination and meristem cell fate by targeting Tasselseed6/indeterminate spikelet1. Nat. Genet. 39: 1517-1521. http://dx.doi. org $/ 10.1038 / \mathrm{ng} .2007 .20$

Chuck G, Meeley R and Hake S (2008). Floral meristem initiation and meristem cell fate are regulated by the maize $A P 2$ genes ids 1 and sid1. Development 135: 3013-3019. http://dx.doi.org/10.1242/dev.024273

Derbyshire P and Byrne ME (2013). MORE SPIKELETS1 is required for spikelet fate in the inflorescence of Brachypodium. Plant Physiol. 161: 1291-1302. http://dx.doi.org/10.1104/pp.112.212340

Faris JD, Fellers JP, Brooks SA and Gill BS (2003). A bacterial artificial chromosome contig spanning the major domestication locus Q in wheat and identification of a candidate gene. Genetics 164: 311-321.

Hall TA (1999). BioEdit: a user-friendly biological sequence alignment editor and analysis program for Windows 95/98/ NT. Nucl. Acid. S. 1: 95-98.

Jenkins G (1973). The effect of sowing date and photoperiod on panicle morphology in naked oats (Avena nuda). Ann. Appl. Biol. 73: 85-94. http://dx.doi.org/10.1111/j.1744-7348.1973.tb01312.x

Jung JH, Seo YH, Seo PJ, Reyes JL, et al. (2007). The GIGANTEA-regulated microRNA172 mediates photoperiodic flowering independent of CONSTANS in Arabidopsis. Plant Cell 19: 2736-2748. http://dx.doi.org/10.1105/ tpc. 107.054528

Kibite S and Taylor JS (1994). Inheritance and linkage relationships of genes conditioning hullessness, multiflorous spikelet and giantism in oat (Avena sativa L.). Can. J. Plant Sci. 74: 497-500. http://dx.doi.org/10.4141/cjps94-090

Klindworth DL, Klindworth MM and Williams ND (1997). Telosomic mapping of four genetic markers in durum wheat. J. Hered. 88: 229-232. http://dx.doi.org/10.1093/oxfordjournals.jhered.a023093

Komatsu M, Chujo A, Nagato Y, Shimamoto K, et al. (2003). FRIZZY PANICLE is required to prevent the formation of axillary meristems and to establish floral meristem identity in rice spikelets. Development 130: 3841-3850. http:// dx.doi.org/10.1242/dev.00564

Ladizinsky G (2012). Studies in oat evolution: a man's life with Avena. SpringerBriefs in Agriculture, New York.

Lawes DA and Boland P (1974). Effect of temperature on the expression of the naked grain character in oats. Euphytica 23: 101-104. http://dx.doi.org/10.1007/BF00032747

Lee DY and An G (2012). Two AP2 family genes, supernumerary bract (SNB) and Osindeterminate spikelet 1 (OsIDS1), synergistically control inflorescence architecture and floral meristem establishment in rice. Plant J. 69: 445-461. http://dx.doi.org/10.1111/j.1365-313X.2011.04804.x

Lee H, Yoo SJ, Lee JH, Kim W, et al. (2010). Genetic framework for flowering-time regulation by ambient temperatureresponsive miRNAs in Arabidopsis. Nucleic Acids Res. 38: 3081-3093. http://dx.doi.org/10.1093/nar/gkp1240

Leggett JM and Thomas H (1995). Oat evolution and cytogenetics. In: The oat crop: production and utilization (Welch RW, ed.). Chapman and Hall, London, 120-149.

Loskutov IG (2008). On evolutionary pathways of Avena species. Genet. Resour. Crop Evol. 55: 211-220. http://dx.doi. org/10.1007/s10722-007-9229-2

Love HH and McRostie GP (1919). The inheritance of hull-lessness in oat hybrids. Am. Nat. 53: 5-32. http://dx.doi. org/10.1086/279691

Ougham HJ, Latipova G and Valentine J (1996). Morphological and biochemical characterization of spikelet development in naked oats (Avena sativa). New Phytol. 134: 5-12. http://dx.doi.org/10.1111/j.1469-8137.1996.tb01141.x

Pellizzaro K, Nava IC, Chao S, Pacheco MT, et al. (2016). Genetics and identification of markers linked to multiflorous spikelet in hexaploid oat. Crop Breed. Appl. Biotechnol. 16: 62-70.http://dx.doi.org/10.1590/1984-70332016v16n1a10

Pennell AL and Halloran GM (1984). Influence of time of sowing, photoperiod, and temperature on supernumerary spikelet expression in wheat. Can. J. Bot. 62: 1687-1692. http://dx.doi.org/10.1139/b84-228

Genetics and Molecular Research 16 (1): gmr16019588 
Poursarebani N, Seidensticker T, Koppolu R, Trautewig C, et al. (2015). The genetic basis of composite spike form in barley and "miracle-wheat". Genetics 201: 155-165. http://dx.doi.org/10.1534/genetics.115.176628

Sayle RA and Milner-White EJ (1995). RASMOL: biomolecular graphics for all. Trends Biochem. Sci. 20: 374-376. http:// dx.doi.org/10.1016/S0968-0004(00)89080-5

Simons MD, Martens JW, McKenzie RIH, Nishiyama I, et al. (1978). Oats: a standardized system of nomenclature for genes and chromosomes, and catalog of genes governing characters. USDA-SEA, Washington.

Sormacheva I, Golovnina K, Vavilova V, Kosuge K, et al. (2015). Q gene variability in wheat species with different spike morphology. Genet. Resour. Crop Evol. 62: 837-852. http://dx.doi.org/10.1007/s10722-014-0195-1

Steel RGD and Torrie JH (1980). Principles and procedures of statistics: a biometrical approach. McGraw-Hill, New York.

Suzuki C, Tanaka W and Hirano HY (2015). Analysis of a rice fickle spikelet1 mutant that displays an increase in flower and spikelet organ number with inconstant expressivity. Genes Genet. Syst. 90: 181-184. http://dx.doi.org/10.1266/ ggs. 90.181

Thompson JD, Higgins DG and Gibson TJ (1994). CLUSTAL W: improving the sensitivity of progressive multiple sequence alignment through sequence weighting, position-specific gap penalties and weight matrix choice. Nucleic Acids Res. 22: 4673-4680. http://dx.doi.org/10.1093/nar/22.22.4673

Valentine J (1995) Naked Oats. In: The oat crop: production and utilization (Welch RW, ed.). Chapman and Hall, London, 505-532.

Vavilov NI (1992). Origin and geography of cultivated plants. Cambridge University Press, Cambridge.

Yanofsky MF, Ma H, Bowman JL, Drews GN, et al. (1990). The protein encoded by the Arabidopsis homeotic gene agamous resembles transcription factors. Nature 346: 35-39. http://dx.doi.org/10.1038/346035a0

Zhang B, Wang L, Zeng L, Zhang C, et al. (2015). Arabidopsis TOE proteins convey a photoperiodic signal to antagonize CONSTANS and regulate flowering time. Genes Dev. 29: 975-987. http://dx.doi.org/10.1101/gad.251520.114

Zhu QH, Hoque MS, Dennis ES and Upadhyaya NM (2003). Ds tagging of BRANCHED FLORETLESS 1 (BFL1) that mediates the transition from spikelet to floret meristem in rice (Oryza sativa L). BMC Plant Biol. 3: 6. http://dx.doi. org/10.1186/1471-2229-3-6

\section{Supplementary material}

Figure S1. Pluviometric precipitation and mean daily maximum and minimum temperatures recorded from plant emergence to maturity on the first and second sowing dates in 2014. Legend: ES1 = plant emergence on the first sowing date; $\mathrm{ES} 2$ = plant emergency on the second sowing date; FS1 = flowering initiation on the first sowing date and; FS2 = flowering initiation on the second sowing date. Source: INMET.

Genetics and Molecular Research 16 (1): gmr16019588 